University of Pennsylvania Carey Law School

Penn Law: Legal Scholarship Repository

Faculty Scholarship at Penn Law

$5-31-2005$

\title{
The Calculation of Prejudgment Interest
}

Michael S. Knoll

University of Pennsylvania Carey Law School

Jeffrey M. Colon

Fordham University School of Law

Follow this and additional works at: https://scholarship.law.upenn.edu/faculty_scholarship

Part of the Litigation Commons

\section{Repository Citation}

Knoll, Michael S. and Colon, Jeffrey M., "The Calculation of Prejudgment Interest" (2005). Faculty Scholarship at Penn Law. 114.

https://scholarship.law.upenn.edu/faculty_scholarship/114

This Article is brought to you for free and open access by Penn Law: Legal Scholarship Repository. It has been accepted for inclusion in Faculty Scholarship at Penn Law by an authorized administrator of Penn Law: Legal Scholarship Repository. For more information, please contact PennlawIR@law.upenn.edu. 
DRAFT-May 31, 2005

\title{
The Calculation of Prejudgment Interest
}

\author{
Michael S. Knoll* \\ University of Pennsylvania Law School and the Wharton School \\ Jeffrey M. Colon** \\ Fordham University School of Law
}

The parties to a lawsuit often turn their attention to prejudgment interest only towards the end of a long and drawn out process. They are often weary, overextended (in terms of their financial and other obligations) and in a rush to bring the matter to a conclusion. Frequently, they have not yet focused on the issue, and so they treat it as an after-thought. That can be an expensive mistake. Because many jurisdictions grant courts wide discretion in calculating prejudgment interest, the area provides lawyers and experts with the opportunity to provide substantial value to their clients, as well as the possibility of costing them a lot of money.

* Associate Dean, Earl Hepburn Professor of Law, and Professor of Real Estate. reserved.

** Associate Professor of Law. Copyright 2005 by Michael S. Knoll and Jeffrey M. Colon. All rights 
The first task of any lawyer or expert working on prejudgment interest should be to ascertain how his jurisdiction treats prejudgment interest. In the United States, there is no single set of rules for prejudgment interest. Instead, different rules apply depending on the jurisdiction whose law applies and perhaps the cause of action under which the plaintiff is seeking to recover. Many states have prescribed very simple rules. For example, some states set a fixed prejudgment interest rate by statute; others tie the rate to an established index. See Philips \& Freeman (2003) for a survey across the states. In these instances, about the only issue left to contend is the length of the prejudgment period.1

Under federal law, however, the situation is very different. There is no federally mandated prejudgment interest rate or index. Instead, federal courts have long recognized that prejudgment interest is an element of complete compensation. The court is supposed to grant prejudgment interest in an amount that will compensate the plaintiff for the defendant's use of its funds from the date of injury until the date of judgment.2 That is to say, prejudgment interest should return the plaintiff to the position it would have been had the defendant compensated it immediately after injuring it. Courts and commentators have also pointed out that prejudgment interest plays an important role in preventing defendants from being unjustly enriched.

By articulating a broad principle-making the plaintiff whole-the courts have left wide open the debate over how to calculate prejudgment interest. Although commentators have

1 Even in those states in which prejudgment interest is fixed by statute, attorneys and litigation experts can still add value. For example, if the statutory rate differs from the theoretically correct rate, the parties will have incentives to alter their litigation strategies.

2 Post judgment interest is granted from the date of judgment until the date of payment. Under federal law post judgment interest is awarded at the fifty-two week Treasury bill rate. 28 U.S.C. $§ 1961$. 
proposed a variety of different methodologies, the federal courts have not consistently adopted any single approach. Moreover, the Supreme Court's most recent pronouncement, Kansas $v$. Colorado, 533 U.S. 1 (2001), makes clear that lawyers and their experts have wide latitude in persuading the court just how much prejudgment interest the defendant should pay in order to make the plaintiff whole. 3

The stakes are often high. When the injury occurred long before the judgment, prejudgment interest can greatly exceed the original judgment. For example, Kansas, in its 1986 complaint against Colorado, sought $\$ 9$ million in damages going back as far as 1950 , plus $\$ 53$ million in prejudgment interest. In 1992, the Seventh Circuit awarded plaintiffs $\$ 65$ million in damages and \$148 million in prejudgment interest in a suit arising out of the grounding of the supertanker, Amoco Cadiz, off the coast of Brittany on March 16, 1978.

Even when the legal resolution occurs quickly, the interest can be large when the judgment is large, especially when interest rates are high. Moreover, because of compounding, even small differences in interest rates can have large effects on the final award. For example, in Amoco Cadiz, a 1 percent increase in the interest rate (100 basis points) would have increased the final award by $\$ 20$ million. For these reasons, the methods courts use to calculate prejudgment interest have important practical significance.

3 The dispute arose out of a violation of the Arkansas River Compact. The compact, negotiated by Kansas and Colorado, and approved by Congress in 1949, provided that future development of the river's basin could not materially deplete the quantity of usable water available to downstream users. 
The rest of this Essay describes the basic principles that should apply in calculating prejudgment interest and extends that analysis to cover a range of special circumstances that frequently arise. This Essay is not a survey of the case law or of the different positions advanced by commentators. Although we endeavor to discuss other methods where appropriate, this Essay describes what we believe to be the proper method based on sound financial principles.

\section{X.1 THE PROBLEM.}

Courts award prejudgment interest to place the parties in the same position they would have been in had the defendant paid the plaintiff an amount equal to the original judgment when the injury occurred.

Courts most often assess the final award by first calculating a multiplier (denoted by $m$ ), which, when applied to the original judgment $(J)$, produces the final judgment $(F V)$ :

$$
F V=J \times m .
$$

Thus, once it has decided liability and calculated the original judgment, the court's role in assessing prejudgment interest reduces to setting the multiplier, $m$. 
Courts commonly compute the multiplier as follows:

$$
m=\left(1+\frac{r_{m}}{n}\right)^{n T}
$$

where $r_{m}$ is the prejudgment interest rate, $n$ is the number of compounding periods in a year, and $T$ is the prejudgment period in years. Accordingly, setting the multiplier entails three tasks: setting the prejudgement interest rate $\left(r_{m}\right)$, calculating the prejudgment period $(T)$, and determining the frequency with which interest is compounded (n).4

\section{X.2 WHICH INTEREST RATE? DEFENDANT'S COST OF UNSECURED BORROWING}

Courts award prejudgment interest to place both the plaintiff and the defendant in the same position that they would have been in had the defendant compensated the plaintiff immediately after the injury. In awarding prejudgment interest, courts typically describe their task as looking for the interest rate that will compensate the plaintiff for delay.

4 The formula assumes that prejudgment interest will be compounded. Although interest in commercial settings is always compounded, courts sometimes award prejudgment interest using simple interest, which is the traditional common law rule. Courts should, however, award compound prejudgment interest. 
The paradigm employed throughout most of this Essay is a suit between two publicly traded corporations with ready access to the capital markets. We also assume that the corporations' investors hold diversified investment portfolios, and so tie up little of their wealth in the litigating corporations. In Section 7, we briefly discuss how to adjust the calculations when the plaintiff is a close corporation or an individual.

The search for the appropriate interest rate begins by examining the plaintiff corporation's balance sheet (using market, not book, values). As a result of the defendant's wrongdoing, the plaintiff either lost an asset or incurred an additional liability. Either effect would reduce the plaintiff's net worth.

The judicial system compensates the successful plaintiff with a monetary award, an asset. If the award were immediate (and costless to obtain), an award equal to the harm would exactly offset the injury, leaving the plaintiff's net worth unchanged. Because the plaintiff does not receive an immediate judgment, the court awards prejudgment interest so that the present value of the eventual judgment equals the present value of the harm.

The assumption that the parties have ready access to the capital markets now comes into play. We use the term judgment asset to mean the claim the plaintiff has against the defendant at the time the defendant injures the plaintiff, later replaced with an award from the court. The court's task is to set the return on the judgment asset that is appropriate for the risk, so that the value of the judgment asset will equal that of the lost asset or offset the new liability. As with 
other assets, the value of a judgment asset to a plaintiff does not depend on the plaintiff's characteristics, but rather on the judgment asset's risk and return. There are two risks associated with the judgment asset, only one of which should be compensated through prejudgment interest.

The first risk is that the courts will not uphold the plaintiff's claim, or, even if they do, they will not grant plaintiff a judgment that fully compensates for its injury. Although this problem and its solution-for the court to increase its judgment by dividing the harm by one minus the probability of error-are both well-known in the law-and-economics literature, courts do not compensate successful plaintiffs for the possibility that they might have erred.5 Moreover, the risk of judicial error is conceptually outside of the realm of prejudgment interest; it is more appropriately addressed before the calculation of prejudgment interest. Accordingly, it would be inappropriate to increase the prejudgment interest rate to reflect the risk of judicial error.

The second risk is that the court will grant the plaintiff a judgment equal to its harm, but that the plaintiff will not collect the judgment in full because the defendant goes bankrupt. If plaintiffs are not compensated for the risk of default, then plaintiffs as a class will be undercompensated; each plaintiff will be undercompensated ex-ante (the judgment asset will be worth less than the asset lost or liability imposed); and each defendant will be unjustly enriched by the wrongdoing (and thus will have an incentive to engage in wrongdoing as a below-marketcost method of raising capital). Therefore, in order to put plaintiffs and defendants all back into

5 If the harm is $\mathrm{H}$ and the plaintiff's probability of success at trial is $\mathrm{p}$, then to compensate for the risk of judicial error, the court should award a judgment, J, not of $\mathrm{H}$, but of $\mathrm{H} /(1-\mathrm{p})$. 
their positions before the injury occurred, plaintiffs must be compensated for the risk that their defendants will default. Accordingly, the prejudgment interest rate should reflect the risk that the defendant defaults.

As with other debt, the risk that a plaintiff will not ultimately collect on its debt (the judgment) does not depend on the plaintiff's assets, liabilities, or capital structure, but rather on the defendant's risk of default. The interest rate that reflects the risk that the defendant does not pay its debts is the defendant's own borrowing rate. In bankruptcy, courts treat legal claims similar to unsecured debt. Therefore, to compensate the plaintiff for delay, the court should award prejudgment interest at the defendant's unsecured borrowing rate. Such an award will allow the judgment asset to grow at the interest rate appropriate for the risk the plaintiff bears, which is the risk that the defendant will default on the judgment.

The above approach to prejudgment interest is sometimes called the coerced loan theory. That phrase underscores the notion that the defendant, by not immediately compensating plaintiff for its harm, has in effect forced the plaintiff to make a loan to defendant equal to plaintiff's harm. Accordingly, compensating the plaintiff for waiting for repayment requires that the court award prejudgment interest at the rate the defendant would pay a voluntary creditor on an otherwise identical loan.

\section{(a) Alternative Rates Do Not Properly Compensate Plaintiffs}


The coerced loan theory has not been universally accepted. Courts, litigants and commentators have suggested awarding prejudgment interest at rates other than defendant's cost of unsecured borrowing. The rates proposed include the return on plaintiff's equity, the plaintiff's cost of capital, the plaintiff's cost of debt, the return on a market index, and the riskfree interest rate. These proposals can be divided into three groups, depending on whether the award of prejudgment interest is based on plaintiff's return on investment, plaintiff's cost of raising funds, or at an interest rate that is independent of both plaintiff and defendant.

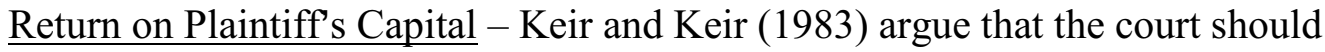
assess prejudgment interest at the average return on plaintiff's equity. Their proffered rationale: had the plaintiff collected the funds, it would have invested in its own business; therefore, the return that the business has produced over time provides the best measure of the amount that the plaintiff lost through delay.

The problem with this argument is that it ignores our assumption that the litigants (especially the plaintiff) are two publicly traded companies with ready access to capital markets. Given that assumption, the defendant's actions cannot plausibly be said to have prevented the plaintiff from foregoing any attractive investment opportunities and thus to have missed out on the resulting return. If the plaintiff did not have the capital to pursue a desirable project, it could have raised the funds through the capital market. 
The Plaintiff's Cost of Capital - Keir and Keir (1983) also argue that the minimum prejudgment interest rate is the plaintiff's cost of capital, which for a firm with both debt and equity, is its weighted average cost of capital.6 Awarding prejudgment interest at the plaintiff's cost of capital is intended to compensate plaintiff for the cost of tying up its capital. The rationale is that awarding prejudgment interest at the plaintiff's cost of capital compensates the plaintiff for the cost it incurred to raise the funds denied it by defendant's wrongdoing.

The Plaintiff's Cost of Borrowing - Closely related to the argument that prejudgment interest should be awarded at the plaintiff's cost of capital is the argument that it should be awarded at the plaintiff's cost of borrowing. The rationale is that if the injury did not prevent the plaintiff from undertaking any investment, then its most likely effect was to cause plaintiff to increase its borrowing (because public firms rarely issue new equity, but they often borrow). Accordingly, in order to return plaintiff to its uninjured state, the defendant should pay interest to the plaintiff at the plaintiff's cost of borrowing additional funds.

Arguments that look at the plaintiff's cost of raising funds (whether its cost of capital or borrowing rate) have an obvious intuitive appeal, but they are also problematic. In many cases, there is no incremental borrowing. In such cases, is there no cost from delay and therefore is no award of prejudgment interest appropriate? Obviously not. Plaintiff is still harmed by waiting and for incurring the risk that the defendant goes bankrupt.

6 Keir and Keir (1983) argue that if a firm's historical return is greater than its weighted average cost of capital, the court should award prejudgment interest at the higher rate; otherwise, the court should award prejudgment interest at the plaintiff's cost of capital. 
If the plaintiff raises additional funds by issuing debt, 7 then the interest rate plaintiff pays for that new capital will reflect the risk borne by those new investors. That risk depends on the assets they can look towards for repayment and their priority. Only in rare instances are the new investors investing only in the claim. When they are, the risks borne by the plaintiff are exactly the same as those borne by the new investors and it is then appropriate to measure the cost to the plaintiff of waiting by the interest rate plaintiff pays to it new investors to bear that risk. 8

In contrast, when the new investors do not look solely to the claim for repayment, then the risk they bear and hence the interest rate plaintiff pays will not reflect the harm caused to plaintiff by delay. In these circumstances, the interest rate plaintiff pays the new investors will reflect their position in plaintiff's capital structure. If the interest rate plaintiff pays its new investors is higher than defendant's unsecured borrowing rate, it is because the plaintiff's new investors are not only assuming the defendant's default risk, but other additional risks as well, for which they demand compensation in the form of a higher interest rate. The defendant should not have to compensate plaintiff for risks unrelated to the litigation that are being transferred to new investors. Alternatively, if the interest rate that plaintiff is paying to outside investors is lower than defendant's cost of unsecured borrowing, then the new investors are not assuming defendant's entire default risk, but instead plaintiff is retaining some of the risk of defendant's

7 Publicly traded firms rarely issue new equity, and so in the text we assume the plaintiff issues debt to raise additional capital. The logic, however, is the same if the plaintiff issues equity except that the return on equity replaces that on debt.

$8 \mathrm{We}$ assume that the plaintiff is certain to succeed on the merits and be granted a judgment (before calculation of prejudgment interest) of a known amount. As discussed elsewhere, prejudgment interest does not compensate successful plaintiffs for their litigation costs or the possibility that they might have lost the case. 
default. The court should not fail to compensate plaintiff for the risk it bears due to defendant's wrongdoing because it raised additional capital without transferring all of that risk to its new investors.

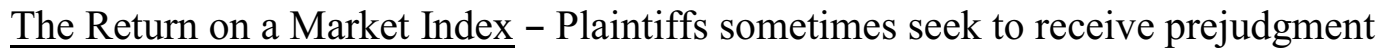
interest at the rate that they would have earned had they received the money earlier and invested it in a diversified portfolio of stocks. The logic is that the plaintiff could have distributed the money to its shareholders, who would have reinvested it. The return on the market portfolio is a reasonable market-based return for a diversified investor. For example, in appraisal cases, the Delaware Court of Chancery awards prejudgment interest based in part on the return that plaintiff could have earned on a diversified portfolio of stocks.9

There are several problems with this argument. First, in the context of litigation between two publicly traded companies, the defendant's actions do not prevent the plaintiff's shareholders from cashing out their stock and investing in a diversified portfolio. They can sell their stock and invest their proceeds as they please. They can also adjust their other investments if they want to increase or decrease their risk exposure.

Second, the return on a diversified portfolio of stocks reflects the risk of that portfolio. That, however, is not the investment that plaintiff has made (albeit involuntarily) with the funds

9 In appraisal cases, the Delaware courts award prejudgment interest in appraisal cases based on an equal weighting of the defendant's cost of borrowing and the return on a "prudent investor" portfolio consisting of a diversified portfolio of stocks, money market instruments, and a bond portfolio. Gonsalves v. Straight Arrow Publishers, Inc., 2002 Del. Ch. Lexis 105. 
held by the defendant. Instead, the plaintiff has, in effect, invested them in the defendant's unsecured debt and should receive a corresponding risk-adjusted return. Giving the plaintiff a different return, based on the risk of a diversified portfolio of stocks, does not compensate the plaintiff for the risk it bore through its forced investment in the defendant.

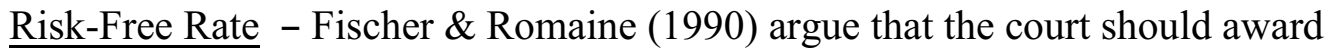
prejudgment interest at the U.S. Treasury bill rate-the interest rate that the federal government pays when it borrows. Their proffered rationale is that U.S. courts do not compensate plaintiffs for the risks of litigation and the possibility of defendant going bankrupt is a risk of litigation. Weil (1995) has two responses to that argument. First, Fisher and Romaine's argument-that plaintiffs should not be compensated for litigation costs-does not imply that prejudgment interest should be awarded at the risk-free rate. Instead, because delay (apart from the risk of default) is also a cost of litigation, the logic of Fisher and Romaine's argument implies that courts should never award prejudgment interest, not that they should award prejudgment interest at the risk-free rate. Since that result is in conflict with statutory law, case law and the logic behind prejudgment interest, the argument upon which it rests should be rejected. Second, awarding prejudgment interest at a fixed or variable rate that is independent of defendant's cost of unsecured debt (such as the risk-free rate), will encourage defendant's to increase their risk. The defendant, through its choice of investments, has some control of its bankruptcy risk. If the prejudgment interest rate does not reflect that risk, the defendant, by increasing that risk, will be able to shift some portion of the costs of risky undertakings to the plaintiff. That would appear to be an unnecessary and undesirable feature of a judicial system. 


\section{(b) Recent Criticisms of the Coerced Loan Theory are Unpersuasive}

In the last couple of years, several commentators have criticized the coerced loan theory and the proposal to award prejudgment interest at defendant's unsecured borrowing rate. We discuss two such commentators next.

Escher and Krueger (2003) employ a cost-of-carry pricing model. They argue that the plaintiff's claim for damages or lost profits (i.e., the judgment asset) is in essence a forward contract that is traded at the time of the harm. The forward contract entitles the plaintiff to receive an amount in the future when the judgment is rendered. The delivery price of such a contract-the amount to be exchanged in the future-is simply today's price (i.e., the harm incurred by plaintiff) plus the cost of carry. In their model, the cost of carry is the plaintiff's "implied financing cost" or cost of debt capital. Escher and Krueger's cost-of-carry approach is insightful, but rather than undercutting the coerced loan theory, it supports it. In the absence of default risk, the delivery price of a forward contract is the spot (or today's) price plus the riskfree rate. As Escher and Krueger note, however, if there is default risk, the difference between the spot price and delivery price should reflect that risk. In the litigation context, because only the defendant can default, only the defendant's default risk matters. Thus, the cost of carry model leads back to awarding prejudgment interest at the defendant's cost of unsecured debt.10

10 This conclusion is consistent with the financial economist's view that the payoff to a long party of a forward contract-the party purchasing the asset, who, in the litigation setting is the defendant-is economically identical to a fully levered position in the underlying asset. Since the leverage is the obligation of the long party (defendant), it is only the long party's (defendant's) default risk that is relevant. 
Barondes (2005) takes a different tack. He argues that the coerced loan theory fails to distinguish between the plaintiff's equityholders and creditors. Drawing on the idea of asset substitution in corporate finance (Jensen \& Meckling (1976)), Barondes notes that the judgment asset, even if it has the same present value as the asset plaintiff lost (or liability it incurred) will likely have different risk characteristics. Substituting a riskier asset for an asset with the same present value will usually transfer value from plaintiff's debtholders to equityholders, and conversely. As a result, awarding prejudgment interest at defendant's cost of unsecured borrowing will not restore plaintiff's equityholders and debtholders positions before the injury. If the judgment asset is riskier than the asset it replaces, equityholders will typically gain at the expense of debtholders, and conversely. The possibility of such a transfer, however, does not provide a basis for rejecting the coerced loan theory. That is because modern finance rejects the view, implicit in Barondes' argument, that equityholders are the firm's owners and debtholders are mere lenders. Rather, in the contemporary view, debt and equity are alternative methods of financing a firm, and it is the firm's investors who are injured. Accordingly, awarding prejudgment interest at the defendant's unsecured borrowing rate will allow debtholders and equityholders taken together to be fully compensated for the risk of the judgment asset without being overcompensated. Using any other interest rate to calculate the final award will either overcompensate or undercompensate some investors in plaintiff. 


\section{X.3 PREJUDGMENT INTEREST SHOULD BE AWARDED AT A FLOATING INTEREST RATE.}

Interest rates usually vary with the duration of an investment. The observed pattern of interest rates from now to various future times is called the term structure of interest rates. Typically, long-term rates exceed short-term rates, producing an upward-sloping term structure.

When, as is normal, the term structure is not flat, the court must decide whether to use a series of short-term rates or a single long-tern rate. Consider, for example, a plaintiff who suffers an injury on January 1, 1996, and receives payment on January 1, 2006. The court, looking backward from the year 2006, might apply the ten-year rate for debt issued by the defendant in 1996 maturing in 2006, or it might apply a series of ten one-year rates-one for 1996, one for 1997, and so on, through 2006. Because the term structure is not usually flat and because it shifts over time, these two choices will give different answers. Typically, but not invariably, the single ten-year rate will exceed the rate compounded from ten one-year rates. Should the court use the ten-year rate or the rate compounded from ten one-year rates? Finance does not provide an answer because either method (if selected ex ante11) would compensate the plaintiff. Knoll (1996), however. argues that the need of the court system to encourage parties to settle their disputes favors using short-term interest rates.

11 Obviously, the court should not allow either party to select the method at the end of litigation. That would give either party a valuable option that would encourage it to delay. 
If courts used long-term interest rates, they would interfere with the parties' incentives to settle. If interest rates rise during litigation, defendants will be borrowing at below-market interest rates, which will give them an incentive to prolong litigation. Falling interest rates reverse the incentives. Thus, although one party's incentive to delay is matched by the other party's incentive to expedite, it is easier for one party acting unilaterally to delay litigation than to expedite it. In contrast, short term rates give neither party an advantage or disadvantage from delay and thus encourage settlement relative to using long-term rates.

The upward-sloping term structure reflects the increasing interest rate risk from fixing an interest rate at the start of ever-longer loans. Because courts set prejudgment interest ex post, after the events have occurred and all interest rates are known for all past periods, the investor (the plaintiff) bears no risk that those past interest rates will change. Accordingly, courts should calculate prejudgment interest using a series of short-term rates, short enough not to include a premium for interest rate risk. This implies computing prejudgment interest based on floating, variable, or adjustable rates, not on fixed rates.

Losey, Mass and Li (2002) disagree. They argue that short-term interest rates will neither discourage foot dragging nor compensate plaintiffs. Instead, they propose that courts should award prejudgment interest at a variable rate with a term premium. That premium serves two functions: compensation for the risk of default and for tying up capital. To the extent that the premium compensates for the risk of default, that issue is discussed below. Here, we discuss only compensation for extending credit for a period of time. 
The standard explanation for the persistence of the upward sloping interest term structure is that borrowers have longer time horizons than lenders. Accordingly, in order to induce borrowers to invest their capital for a long period, borrowers must receive a premium. It is important to distinguish between a term premium and a liquidity premium. Holders of long-term federal government securities, however, do not have to tie up their money. That is because the market for such securities is highly liquid. The holder of a one-year bond can get his money in one year; the holder of a ten-year bond can also get her money in one year, by selling her bond. The latter however is subject to more risk because the price she gets for her bond will depend on the 9-year interest rate in one year. The term premium reflects this risk, which can be avoided by granting prejudgment interest at a variable or floating interest rate. 12

\section{X.4 ESTIMATING DEFENDANT'S UNSECURED FLOATING BORROWING RATE}

According to the coerced loan theory, the court should award prejudgment interest at the interest rate the defendant would pay on an otherwise equivalent voluntary loan. Because the judgment is treated on par with unsecured creditors in bankruptcy, prejudgment interest should be granted at the interest rate the defendant would pay for unsecured debt in order to compensate the plaintiff for the risk of default. In order to avoid the possibility of having both a large winner and a large loser when interest rates change, prejudgment interest should be granted at a floating or variable interest rate.

12 That is not to say that there is no cost to plaintiff from tying up the money or more accurately that the market does not pay a premium for tying up capital. However, such a premium, if it exists, is not given by the yield curve premium. 
Courts have several methods available to them to estimate the interest rate that the defendant would pay on an otherwise identical voluntary loan. We discuss three relatively simple to implement methods here. They all yield approximations. Although none of the methods will yield a precise, theoretically correct answer, they will produce credible results when done with some care.

The coerced loan theory says that prejudgment interest should be awarded at the interest rate defendant pays for unsecured borrowing. In order to compensate the plaintiff for the risk of nonpayment the prejudgment interest rate should reflect the risk to the plaintiff that the defendant will default. The most obvious proxy is a floating interest rate at which the defendant can or is borrowing unsecured. For companies that can borrow large sums from banks without security, the prime rate is an obvious proxy.

Second, many large companies have access to and regularly borrow through the commercial paper market. Commercial paper is short-term, unsecured promissory notes. Because the commercial paper market is more restrictive than the market for bank loans at prime, the interest rate on commercial paper is regularly 200 to 300 basis points below the prime rate. As a result, only the most creditworthy borrowers can issue commercial paper.

Losey, Mass and Li (2002) take issue with awarding prejudgment interest at the defendant's commercial paper rate. They argue that the short-term commercial paper rate does not compensate plaintiff for the risk that the defendant will go bankrupt before the judgment can 
be enforced. That is because the risk of bankruptcy increases with the horizon, and most plaintiffs have been forced into making a long-term loan (perhaps many years in duration) to the defendant, whereas the holders of commercial paper typically make loans for a year or less.

Accordingly, to compensate for this risk, it may be appropriate to use the defendant's long-term variable interest rate. Because a defendant may not have any long-term variable interest rate debt outstanding, a court may have to estimate what that rate would be using the bond-rating services rating of the corporation's unsecured long-term debt and information on the risk premium for long-term debt of that same rating.13 Financial services, such as Bloomberg, publish yield curves for corporate debt with different ratings from the credit agencies. They also calculate the yield premium relative to Treasury securities. The premium not over short-term rates, but relative to Treasury securities with the same maturity will reflect the additional credit risk with corporate securities. That information can be used to estimate the appropriate prejudgment interest rate.

\section{X.5 COMPLETING THE MULTIPLIER.}

The previous sections discussed how the court should select the prejudgment interest rate. Setting the multiplier requires that the court also determine the length of the prejudgment period (T) and the choice of compounding period (n). It is to these issues that we now turn.

13If a defendant has outstanding long-term variable interest rate debt, the rate on the that debt could be used provided that adjustments are made for the value of any put and call provisions held by the holder or issuer. 


\section{(a) The Prejudgment Period.}

The courts second task is to calculate the length of the prejudgment period. That period ends at the award date.14 That leaves two open issues: when to begin the prejudgment period and whether to deny interest for a portion of the prejudgment period. To aid in our discussion, consider the following dates (terminology adapted from Weil): incident date, harm date, filing date, and award date.

Consider first when the court should begin the prejudgment period. Jurisdictions split between those that begin to accrue interest from the harm date (usually, but not necessarily, the incident date) and those that wait until the filing date. The recognition that prejudgment interest compensates for the defendant's possession of funds that rightfully belong to the plaintiff favors using the harm date. That will place the plaintiff in the same position as if the defendant had immediately paid the plaintiff, which is the purpose served by prejudgment interest.

Courts sometimes deny interest to plaintiffs who have unduly delayed the filing date under the doctrine of laches. Denying plaintiffs compensation for harm they themselves caused by waiting might be a suitable reaction if the court awards prejudgment interest at a rate higher than the defendant's unsecured debt rate. If, however, the court sets the rate correctly, then not commencing the accrual of interest at the date of harm fails to compensate the plaintiff fully and undercharges the defendant. Even if the plaintiff has unduly delayed, the defendant is not

14 The prejudgment period ends when the court issues its judgment. Frequently, because of appeals, collateral litigation, and the possibly delays in collection, the plaintiff is not paid until later. The period from judgment to payment is the postjudgment period. 
penalized by accruing interest over the entire prejudgment period. The defendant will break even, having held the funds during the delay period, for which the court charges it at its normal borrowing rate for such funds.

\section{(b) Choice of Compounding Period.}

The courts last task in setting the multiplier is to select the compounding period-an issue that the parties and the courts frequently overlook. All interest rates explicitly or implicitly assume a compounding period. Consider a stated annual interest rate of 12 percent. With a compounding period of one year, the effective annual rate equals 12 percent. If, however, the compounding period is the calendar quarter, implying a rate of $3(=12 / 4)$ percent per quarter, the effective annual rate is $12.55\left(=1.03^{4}-1\right)$ percent. If the compounding period is one month, implying a rate of $1(=12 / 12)$ percent per month, the effective annual rate is $12.68\left(=1.01^{12}-1\right)$ percent.

The effects of the choice of compounding period on the award can be substantial. The defendant pays dollars, not percentages. For example, the Amoco Cadiz court awarded interest at the prime rate compounded yearly. The court did not take into account the practice that prime rate loans typically call for quarterly interest compounding. Knoll (1996) estimates that adjusting the interest rate calculation for the more frequent compounding that the quoted rate presumes would have increased the interest component of the award by about $\$ 11$ million. 


\section{X.6 OTHER ISSUES IN THE CALCULATION OF PREJUDGMENT INTEREST}

This section discusses several additional issues in the calculation of prejudgment interest: taxes; multiple defendants; the relation between prejudgment interest and currency conversion; and injuries that produce harms at a later date.

\section{(a) Adjusting the Multiplier for Taxes}

The discussion so far has ignored income taxes. In order to ensure that the award compensates plaintiff without being overly generous, the court should adjust its calculation for taxes. That is because the tax treatment of prejudgment interest generally does not mirror the tax treatment of corporate bond interest.

The interest earned on bonds is taxed as it accrues. In contrast, even accrual method plaintiffs do not pay tax on prejudgment interest until the award date. Compared to receiving compensation immediately at the time of harm and investing the proceeds in taxable bonds, the plaintiff has been able to defer its tax payments on its interest earnings to the award date. To adjust for the benefit of deferral, the court should compound prejudgment interest at the product of defendant's cost of unsecured borrowing and one minus the plaintiff's tax rate over the prejudgment period, 15 and then gross up that after-tax amount by dividing by one minus

15 Implicit taxes (in the form of lower expected rates of return) on some investments, such as municipal bonds, are taxes for this purpose. 
plaintiff's tax rate on the award date. When the court takes into account the tax on prejudgment interest, the multiplier, denoted by $m_{A T}$, becomes:

$$
m_{A T}=\frac{\left(1+\frac{\gamma_{m}^{A T}}{n}\right)^{n T}-1}{1-t_{T}}+1
$$

where $\mathrm{t}_{\mathrm{T}}$ is the tax rate in year $T$ and $r_{m}{ }^{A T}$ is the mean after-tax interest rate, with $r_{i}^{A T}=r_{i}\left(1-t_{i}\right)$.

The court might also need to adjust the multiplier to reflect the tax treatment of the original judgment. Equations (2) and (3) implicitly assume that the plaintiff would not have paid any taxes if the defendant had immediately compensated the plaintiffs, and so the plaintiff could have invested the entire payment. If, however, the plaintiff would have had to pay taxes on any payment received from the defendant, then the plaintiff would have ben able to invest only the after-tax amount, and so would not have earned as much interest. Accordingly, when the original judgment is taxable, the multiplier, now denoted by $m^{\prime}{ }_{A T}$ is

$$
m_{A T}^{\prime}=\frac{\left(1-t_{0}\right)\left(1+\frac{\gamma_{c}^{* T}}{n}\right)^{n T}}{1-t_{T}},
$$


where $t_{T}$ and $r_{M}{ }^{A T}$ are as defined in equation (3) and $t_{o}$ is the tax rate at the time of injury.

Multipliers calculated using equation (3) will usually exceed those calculated using equation (4).

Which multiplier the court should use depends upon plaintiff's tax status and the taxability of the award. If plaintiff is exempt from tax, the court should use equation (2). If the plaintiff is subject to tax on taxable interest income, the court should use either equation (3) or equation (4). If the award is also taxable, then equation (4) gives the correct multiplier. On the other hand, if the award is not taxable, then equation (3) gives the correct multiplier. In general, the award is taxable it if it compensates the plaintiff for lost income, but not if it compensates for an otherwise deductible loss.16 For example, assume a contract case in which the court awards the plaintiff expectancy damages of $\$ 1$ million- $\$ 600,000$ as compensation for expenses incurred and $\$ 400,000$ for anticipated profit. Then, the court should assess prejudgment interest on $\$ 600,000$ using equation (3)-because that portion of the payment is in effect untaxed assuming that the deduction was suspended until payment-and on the remaining $\$ 400,000$ using equation (4)-because that portion of the payment is taxed.17

In at least two cases, Hughes Aircraft Co. v. United States, 31 Fed. Cl. 481 (1994), affld, 86 F.3d 1566 (Fed. Cir. 1996) and Cement Division, National Gypsum Co. v. Milwaukee, 950 F. Supp. 904, affld, 144 F.3d 1111 ( $7^{\text {th }}$ Cir. 1998), defendants argued that the court should adjust

16 In the latter circumstance, no deduction is generally allowed while the case is in litigation.

17 Equations (3) and (4) both include the plaintiff's tax rate. That rate should be the plaintiff's marginal tax rate on the amount at issue. That rate will often differ from the effective tax rate that is reported in the plaintiff's financial reports (Scholes et al. (2005)). The appropriate rate is also effected by the tax planning strategies available to plaintiff (Weil (1995)). 
the multiplier for the deferral of taxes. In neither case, did the court adjust the multiplier for taxes. In Cement Division, however, the district court, to which defendant had submitted a working paper version of Knoll (1996), stated that the proposed adjustment "would result in a more accurate calculation." Nonetheless, it declined to do so, noting that the record did not contain sufficient information about plaintiff's income or taxes to calculate the adjustment and that no other court had previously done so.

\section{(b) Multiple Defendants.}

In many cases, the plaintiff can collect its judgment, if at all, only from the defendant. In such cases, awarding prejudgment interest at defendant's cost of unsecured debt compensates plaintiff for the risk of default. In other cases, however, the defendant can collect from more than one source. When the plaintiff can recover from more than one party, the court should take this possibility into account in setting the prejudgment interest rate. In general, because the opportunity to look towards multiple sources increases the likelihood of recovery, it should reduce the prejudgment interest rate.

For example, when the court finds several defendants jointly and severally liable, a successful plaintiff will fail to collect the full judgment only if all liable defendants default. Because the plaintiff will collect the entire judgment if any defendant is solvent, the plaintiff should be awarded prejudgment interest at the market interest rate for an unsecured loan jointly made to (or guaranteed by) all the liable defendants. The interest rate for such a loan cannot exceed-and will usually be less than-the rate paid by the most creditworthy defendant. 
When the defendant carries insurance, the successful plaintiff can then look both to the defendant and to its insurance company for recovery. When the plaintiff is covered by insurance that the defendant had in place on the injury date, the plaintiff will recover if either the defendant or its insurer is solvent. In such circumstances, prejudgment interest should not exceed the lesser of the defendant's and its insurance carrier's unsecured borrowing rate.

This issue also arises when the defendant is part of an affiliated group of companies. Under such circumstances, a dispute can arise as to which companies within the group can be forced to pay the judgment if the defendant cannot. For example, a wholly owned subsidiary of Amoco operated the supertanker Amoco Cadiz. If the court finds the subsidiary liable but not the parent, the plaintiffs could look to only the subsidiary's assets to satisfy a judgment. Although the plaintiffs would ex ante be less likely to collect their judgment, they should receive compensation for this additional risk through a higher prejudgment interest rate based on the subsidiary's unsecured borrowing rate only, unprotected by the parent. Accordingly, the court should base the interest rate on the default risk of the subsidiary, or group of companies, whose assets defendants can reach to satisfy its judgment. 18

\section{(c) Currency Conversion.}

18 Parent-subsidiary liability has the potential to create a strategic issue because a defendant whose subsidiary is sufficiently solvent to pay the judgment has an incentive to concede the parent's responsibility assuming the subsidiary is liable at the end of the process in an attempt to keep the prejudgment interest rate down. 
Regardless of where an injury occurs and the currency in which the harm is originally denominated, U.S. courts usually grant the final award in dollars. Thus, when the harm is not originally denominated in dollars, setting the final judgment requires two steps: converting the award into dollars and calculating prejudgment interest.

The court can calculate the final judgment in two ways. First, it can convert the original award to dollars using the exchange rate at harm date and then calculate prejudgment interest using the defendant's unsecured borrowing rate for dollar-denominated loans. Alternatively, a court can calculate prejudgment interest using the defendant's unsecured borrowing rate in the currency in which the harm occurred and then convert the award to dollars using the exchange rate at the judgment date.

The order in which the court performs those two steps matters. Using actual interest rates and exchange rates, the two techniques usually produce different results. That is because exchange rates and interest rates move over time in ways that are not completely anticipated. The wider the fluctuations, the greater the difference in results.19 Accordingly, the sequence in which the calculations are made matters. Neither sequence is wrong. However, neither party should be permitted to choose the method it prefers at the end of litigation. That party would obviously choose the method that was more advantageous to it. Instead, courts should develop a consistent methodology.

19 The possibility of arbitrage will ensure that the two techniques will yield the same final judgment using long-term interest rates over the entire prejudgment period in both markets and the forward foreign currency-dollar exchange rate as of the date of harm. This equivalence however does not hold for shorter-term interest rate and spot exchange rates. 
A simple rule would be for courts to follow the current jurisprudence on exchange rate conversions. The prevailing approach is to look at the jurisdiction in which plaintiff's cause of action arose to determine when to convert the award into dollars. Only when the plaintiff's cause of action arises entirely under foreign law is the judgment converted on the judgment date. If, however, the plaintiff has a claim arising under U.S. law, the judgment will be converted into U.S. dollars as of the harm date. As long as the approach used by the court is determinative early in the process, there will be little opportunity for strategic action.

\section{(d) Payments for Subsequent Harms.}

The discussion so far has dealt with harms that occur at a single date or over a short period of time around the time of the injury. Thus, for example, in Amoco Cadiz, the harm was the cost of cleaning up the beaches and waterways damaged by the oil spill. Barondes (2005) has shown that there is a risk of double counting when the harm occurs subsequently. In such circumstances, the appropriate response is usually to discount the subsequent harm back to the date of injury (using an interest rate appropriate for the project) and then to calculate prejudgment interest on that amount until the judgment date. This will produce a different result than just bringing the harm to the judgment date whenever the discount rate on the project differs from the prejudgment interest rate. See Weil (2003).

Consider the following example. An oil spill occurs on January 1, 1996, and the final judgment is rendered on January 1, 2006. A portion of the judgment covers the harm from the 
lost fish catch in 1999 (assumed to incur on January 1, 1999 to keep the arithmetic simple). Since the judgment is rendered on January 1, 2006, the payment must be brought to that date. That can be done in either one of two ways. Prejudgment interest can be calculated from 1999 to 2006, a period of 7 years. Alternatively, the value of the lost catch can be discounted from 1999 back to 1996, a period of 3 years, and prejudgment interest then calculated from 1996 to 2006, a period of 10 years.

Which approach the court should use depends on the nature of the injury. If the lost fish catch in 1999 was a result of the 1996 oil spill and was unlikely to be remedied by subsequent remedial actions, then as of 1996 the plaintiff had to look towards the defendant for the lost catch in 1999. Accordingly, the court should discount the value of the catch back to 1996 and then calculate prejudgment interest until 2006. Alternatively, if the defendant could have remedied the harm by taking reasonable steps at remediation, but it still failed to remedy the harm, then the plaintiff's injury can be traced to 1999. Accordingly, prejudgment interest should be awarded for 7 years, from 1999 through 2006.

\section{X.7 CLOSE CORPORATIONS AND INDIVIDUAL PLAINTIFFS}

The analysis and conclusions given above must be modified if the plaintiff is an individual or small business. In such cases, the defendant's unsecured borrowing rate will not be the appropriate rate in all cases. 20

20 If the plaintiff is a publicly traded corporation and the defendant an individual or small business, then a 
The argument for awarding prejudgment interest at the defendant's unsecured borrowing rate was based on two key premises. The first premise-that the plaintiff had ready access to the capital markets-ensured that the defendant's actions would not prevent the plaintiff from making any desirable investments. This took away the argument that the plaintiff should be compensated for a missed opportunity. The second premise-that investors in the plaintiff had little of their wealth tied up in the plaintiff and held diversified investment portfolios-ensured that they would value the claim in the same manner as would the market. This implied that they require compensation for the risk associated with the claim in exactly the amount that the market would pay if the claim were a separately traded asset. Together, the two premises directly led to the conclusion that awarding prejudgment interest at the defendant's cost of unsecured debt would compensate plaintiff (and its investors) for the delay in receiving judgment.

For close corporations and individuals, the two premises might not hold. Specifically, when the claim is large relative to the plaintiff's wealth, the premises are likely to be violated. In those circumstances, it is possible that the plaintiff was prevented from making a desirable investment (or at least the cost of such investment was increased), forced to change his or her

court should still award prejudgment interest using the defendant's unsecured borrowing rate. The plaintiff has made a forced loan to the defendant and must be compensated for the risk that the defendant won't pay any final judgment. Unlike the case of corporate defendants, there is no readily available interest rate a court could look to in order to set the appropriate prejudgment interest rate. Home mortgage and car loan rates are not appropriate benchmarks because such loans are secured. The rate on credit card debt is probably better because it is unsecured. Credit cards rates, however, vary greatly and are relatively high. If this benchmark is used, the defendant would greatly benefit by being able to show that he or she would be eligible for a rate on the low end of the range. As described above, to the extent that a judgment was covered by insurance, the insurance company's unsecured borrowing rate would be the appropriate rate. 
consumption, and that the plaintiff does not value the claim in the same way as would the market.

The unsecured borrowing rates of publicly traded corporations are set in the marketplace by the buying and selling actions of diversified investors. The equilibrium market rate, and in particular, the excess of the promised rate over the risk-free rate, will reflect the expected default loss and, to extent the marginal investor is risk adverse, an additional premium over the risk-free rate.

If the plaintiff's claim is large relative to his or her wealth, the forced loan to defendant would cause plaintiff to hold an undiversified portfolio and bear unsystematic risk that is not priced into the defendant's borrowing rate. Thus, receiving the defendant's unsecured borrowing rate would under compensate the plaintiff. In theory, to properly adjust this rate, a court would need to determine the plaintiff's subjective degree of risk aversion. The plaintiff, of course, would have a great incentive to exaggerate his or her degree of risk aversion.

In addition, the delay in receiving the judgment proceeds and interest may prevent an individual from exercising his or her optimal consumption during litigation. Although it may be proper to adjust the rate to reflect the plaintiff's diminished utility, the precise mechanism for doing so is unclear as it necessarily depends on subjective information from the plaintiff.

\section{X.8 CONCLUSION}


This Essay has set forth the appropriate method for assessing prejudgment interest in litigation and has demonstrated how to apply the rate in different situations. We argue that in suits between two parties with ready access to the capital markets, prejudgment interest should be calculated using the defendant's unsecured, short-term borrowing rate with possible adjustment for the risk that the defendant will default. If done well, such an award will compensate the successful plaintiff for the delay in receiving payment and for the risk that the defendant will go bankrupt before the plaintiff can collect. It will also prevent the defendant from being unjustly enriched without further penalizing the defendant. Further, by calculating prejudgment interest at a floating rate over the prejudgment period instead of at a fixed, longterm interest rate at the start of the period, the court can eliminate the risk of interest rate changes.

There are many benefits to using the defendant's unsecured, floating borrowing rate. Once litigation has begun, judicial resources are economized because neither party has an incentive to unnecessarily delay litigation. Prior to litigation, because defendants who are found liable must pay and successful plaintiffs will receive complete economic compensation for damages, both parties will have the proper economic incentives to take the correct amount of care, thereby improving efficiency. 


\section{CASES}

Cement Division, National Gypsum Co. v. Milwaukee, 950 F. Supp. 904, aff'd, 144 F.3d 1111 ( $7^{\text {th }}$ Cir. 1998).

Gonsalves v. Straight Arrow Publishers, Inc., 2002 Del. Ch. Lexis 105 (2002).

Hughes Aircraft Co. v. United States, 31 Fed. Cl. 481 (1994), aff'd, 86 F.3d 1566 (Fed. Cir. 1996).

In Re Oil Spill by the Amaco Cadiz off the Coast of France on Mar., 16, 1978, 954 F.2d 1279 ( $7^{\text {th }}$ Cir. 1992) (per curiam).

Kansas v. Colorado, 533 U.S. 1 (2001).

\section{BIBLIOGRAPHY}

David E. Ault \& Gilbert L. Rutman, The Calculation of Damages Awards: The Issue of पPrejudgment Interest," 12 J. ForensiC ECON. 97 (1999).

Royce de R. Barondes, Rejecting the Marie Antoinette Paradigm of Prejudgment Interest, 43 Brandeis Law Journal 1 (2004).

Harold Dilbeck, The Time Value of Money, Litigation Services Handbook: The Role of the AcCOUntAnt As ExPERT ch 38 (Roman Weil et al. eds., 2d ed. 1995).

Susan Escher \& Kurt Krueger, The Cost of Carry and Prejudgment Interest, 6 Litig. EcON. REV. 12 (2003).

Merle Erickson \& James K. Smith, Tax Treatment of Damages Awards, Litigation SERviceS Handbook: The Role of the Financial Expert ch 14 (Roman Weil et al. eds., 3d ed. 2001 \& Supp. 2005).

Franklin M. Fisher \& R. Craig Romaine, Janis Joplin's Yearbook and the Theory of Damages, 5 J. Acct. Auditing \& Fin. 145 (New Series 1990).

Cornelius A. Hoffman, Risk-Free Rates, Litigation Services Handbook: The Role of the Accountant As Expert ch 39 (Roman Weil et al. eds., 2d ed. 1995). 
Michael C. Jensen \& William H. Meckling, Theory of the Firm, Managerial Behavior, Agency Costs and Ownership Structure, 3 J. OF FIN. ECON. 305 (1976).

Elo R. Kabe \& Brian L. Blonder, Discounting Concepts and Damages, Litigation Services Handbook: The Role of the Accountant as Expert ch 37A (Roman Weil et al. eds., 2d ed. 1995 \& Supp. 1997).

John C. Keir \& Robin C. Keir, Opportunity Cost: A Measure of Prejudgment Interest, 39 Bus. LAW. 129 (1983).

Robert L. Losey et al., Prejudgment Interest: The Long and the Short of It, 15 J. ForENSIC ECON. 57 (2002).

Michael S. Knoll, A Primer on Prejudgment Interest, 75 Tex. L. REv. 293 (1996).

Michael S. Knoll, Primer on Prejudgment Interest, Litigation Services Handbook: The Role OF THE FinANCiAL EXPERT ch 8B (Roman Weil et al. eds., 3d ed. 2001 \& Supp. 2005).

Robert F. Lanzillotti \& Amanda K Esquibel, Measuring Damages in Commercial Litigation: Present Value of Lost Opportunities, 5 J. Acct. Auditing \& Fin. 125 (New Series 1990).

James M. Patell et al., Accumulating Damages in Litigation: The Roles of Uncertainty and Interest Rates, 11 J. Legal STud. 341 (1982).

John R. Philips \& Neill W. Freeman, Interest as Damages, Litigation Services Handbook: The Role of the Financial Expert ch 9 (Roman Weil et al. eds., 3d ed. 2001 \& Supp. 2005).

Myron R. Scholes et al., TaXes and Business Strategy (3d ed. 2005).

Roman L. Weil, Compensation for the Passage of Time, Litigation Services Handbook: The Role OF THE AcCountant AS EXPERT ch 37 (Roman Weil et al. eds., 2d ed. 1995).

Roman L. Weil, Compensation for Asynchronous Payments, Litigation Services Handbook: The Role of the Financial Expert ch 8A (Roman Weil et al. eds., 3d ed. 2001 \& Supp. 2005). 